\title{
The Effect on Late Pregnancy Feed Allowance on the Composition of the Sow's Colostrum and Milk
}

\author{
By Leif Göransson
}

Department of Animal Nutrition and Management, Swedish University of Agricultural Sciences, Uppsala, Sweden.

\begin{abstract}
Göransson, L.: The effect of late pregnancy feed allowance on the composition of the sow's colostrum and milk. Acta vet. scand. 1990, 31, 109-115. - The composition of colostrum and milk of sows fed either $3.4 \mathrm{~kg}$ or $1.0 \mathrm{~kg}$ daily of a conventional sow diet during the last 14 days of gestation was investigated. The fat content of colostrum of the very restrictedly fed sows was higher compared with the standard fed sows. There was a significant decrease in the crude protein and immunoglobulin contents of colostrum during the first $4 \mathrm{~h}$ post farrowing. The milk composition 14 days after farrowing was not affected by the late pregnancy feeding level. The composition of milk was significantly correlated with the 3 week litter weight. The colostrum IgG content was not correlated to the mortality of piglets during the first week post farrowing. The content of crude protein and immunoglobulins in the milk was not correlated with the frequency of post weaning diarrhoea.
\end{abstract}

late pregnacy feeding; colostrum composition; milk composition; neonatal mortality; production performance; post weaning diarrhoea.

\section{Introduction}

The yield and composition of the sow's colostrum and milk are of great importance for the growth and development of the piglets. A high piglet mortality was found to be correlated with a low level of IgG in the blood (Yugachi et al. 1980). Sows in good condition were reported to produce milk with a higher fat and energy content compared with thin sows (Elsley 1970, O'Grady et al. 1973). Hovell \& MacPherson (1977) found that sows given half the A.R.C. (1967) recommended amounts of energy and protein produced lower amounts of milk compared with sows fed according to the recommendation. Additionally, the milk fat content of the sows on the low feeding level was lower than the corresponding values of the norm fed sows. These findings were supported by $\mathrm{Kla}$ - ver et al. (1981), who also reported selected thin lactating sows on a low feeding level to have higher milk fat content compared with selected thin sows on a high feed allowance. No differences in colostrum or milk yield and composition was found by Nielsen \& Danielsen (1983), when sows in late pregnancy were fed either a moderate or a high feed allowance.

The main aim of this investigation was to examine the effect of very restricted late pregnancy feeding on the occurrence of agalactia in the sow. This report covers the effect of a very low late pregnancy feeding level on the composition of sow's colostrum and milk. The effects on lactation failure and production traits have been reported elsewhere (Göransson 1988, Göransson 1989, Persson et al. 1989). 


\section{Material and methods}

The experiment was performed at the Pig Research Unit of the Department of Animal Nutrition and Management of the Swedish University of Agricultural Sciences. Thirty nine pairs of full sibs (Swedish Landrace $\mathrm{x}$ Swedish Yorkshire) were used for the experiment. If possible the sows were allowed to farrow 6 times. Of the 39 pairs, 24 entered the experiment as gilts. All sows were fed a conventional Swedish sow diet (Table 1). The control group (C) sows were given 2.4 $\mathrm{kg}$ daily during the first 100 days of gestation, and thereafter $3.4 \mathrm{~kg}$ per day. The very restrictedly fed $(R)$ sows were given $1.0 \mathrm{~kg}$ daily during the last 2 weeks of pregnancy. The $\mathrm{R}$ sows were compensated in mid pregnancy (day 30 to day 100) for the low late pregnant feed allowance in order to equalize the total amount of feed given. After farrowing the daily feed allowance was successively increased for all sows to a maximum level of $4.0 \mathrm{~kg}+0.2 \mathrm{~kg}$ per piglet within a period of 3 weeks. The sows were at all times provided with straw for bedding and were free to consume as much as they wanted to. Weaning took place at 6 weeks of age. Every incidence of diarrhoea was recorded litter wise.

Colostrum was obtained from some randomly selected teats after an intramuscular injection of oxytocin. Two weeks after farrowing milk was obtained according to the same procedure after removal of the litter for $1 \mathrm{~h}$ before sampling.

For determination of the dry matter content a few grams of the sample were weighed on an aluminium platlet with a cotton filter in the bottom, dried for 5 at $105^{\circ} \mathrm{C}$, chilled in an dessiccator and weighed. The crude protein was analysed according to the Kjeldahl method. The Lindström method was used for the fat analyses. After addition of sulphuric acid and centrifugation in capillary tubes at $4000 \mathrm{r} / \mathrm{m}$ at a temperature of $60^{\circ} \mathrm{C}$ for $5 \mathrm{~min}$ the fat content was measured. The residual solids were calculated as the difference between the sum of fat and crude protein and the dry matter. A randomly selected number of colostrum and milk samples was analysed for IgA and IgG using the nephelometric assay by polyethyleneglycol induced immunocomplex formation according to $\mathrm{Li}$ zane \& Hellsing (1974). Purified porcine IgA and IgG were used as a control standard. The number of samples analysed is given in Table 2.

The time of the day when the sows farrowed and when the colostrum was obtained were recorded. When the sows farrowed in the late evenings and during the night, the time of farrowing was subjectively estimated. The time of farrowing was used when the time between farrowing and sampling of colostrum was calculated.

Statistical analyses were performed in SAS

Table 1. Composition of the sow diet.

\begin{tabular}{|c|c|c|c|}
\hline \multicolumn{2}{|c|}{ Biological composition $\%$} & \multicolumn{2}{|c|}{$\begin{array}{c}\text { Chemical composition }(C=\text { calcula- } \\
\text { ted, } A=\text { anlysed })\end{array}$} \\
\hline Barley & 59.1 & $\mathrm{MJ} \mathrm{ME} / \mathrm{kg}$ & 11.5 \\
\hline Oats & 20.0 & Crude protein, $\%(\mathrm{C})$ & 14.9 \\
\hline Wheat bran & 5.0 & Crude protein, $\%(\mathrm{~A}, \mathrm{n}=36)$ & 14.9 \\
\hline Alfalfa meal & 5.0 & Digestible crude protein, & \\
\hline Soja bean meal & 4.0 & $\%(C)$ & 11.5 \\
\hline Fish meal & 2.0 & $\mathrm{Ca}, \%(\mathrm{C})$ & 0.82 \\
\hline Meat and bone meal & 2.0 & $P, \%(C)$ & 0.60 \\
\hline Minerals + vitamins & 2.9 & & \\
\hline
\end{tabular}


Table 2. The number of colostrum and milk samples analysed.

\begin{tabular}{|c|c|c|c|c|c|c|c|c|c|c|}
\hline \multirow[t]{3}{*}{ Parity } & \multirow{2}{*}{\multicolumn{2}{|c|}{$\begin{array}{c}\text { DM, CP, } \\
\text { fat } \\
\end{array}$}} & \multicolumn{4}{|c|}{ Colostrum } & \multicolumn{4}{|c|}{ Milk } \\
\hline & & & \multicolumn{2}{|c|}{ IgG } & \multicolumn{2}{|c|}{$\operatorname{Ig} \mathbf{A}$} & \multicolumn{2}{|c|}{$\mathrm{IgG}$} & \multicolumn{2}{|c|}{ IgA } \\
\hline & $\mathrm{C}$ & $\mathbf{R}$ & $\mathrm{C}$ & $\mathbf{R}$ & $\mathrm{C}$ & $\mathbf{R}$ & $\mathrm{C}$ & $\mathbf{R}$ & C & $\mathbf{R}$ \\
\hline 1 & 24 & 24 & 14 & 19 & 8 & 12 & 19 & 15 & 13 & 13 \\
\hline 2 & 30 & 27 & 19 & 18 & 11 & 12 & 20 & 19 & 10 & 12 \\
\hline 3 & 36 & 34 & 26 & 29 & 7 & 10 & 27 & 23 & 6 & 7 \\
\hline 4 & 37 & 36 & 18 & 20 & 3 & 3 & 19 & 20 & 3 & 3 \\
\hline 5 & 35 & 33 & 19 & 17 & 3 & 1 & 17 & 18 & 1 & 0 \\
\hline 6 & 27 & 26 & 10 & 9 & 0 & 1 & 11 & 8 & 0 & 0 \\
\hline Sum & 189 & 180 & 106 & 112 & 32 & 39 & 113 & 103 & 33 & 35 \\
\hline
\end{tabular}

(SAS Institute Inc., 1985) according to the models described below.

Model I $\quad Y_{i j k l}=\mu+f_{i}+p_{j}+h_{k}+e_{i j k l}$

Model II $Y_{i k l}=\mu+f_{i}+h_{k}+e_{i k l}$

Model III $Y_{i j k l}=\mu+f_{i}+p_{j}+b_{1} X 1_{i j k l}+e_{i j k l}$

Model IV $Y_{i j k l}=\mu+f_{i}+p_{j}+b_{2} X 2_{i j k l}+e_{i j k l}$

$\mathrm{Y}_{\mathrm{i}(\mathrm{j}) \mathrm{kl}}=$ recorded value

$\mu \quad=$ general mean

$\mathrm{f}_{\mathrm{i}} \quad=$ effect of feeding $(\mathrm{i}=\mathrm{C}$ or $\mathrm{R})$

$p_{j} \quad=$ effect of parity $(j=1,2 \ldots 6)$

$h_{k} \quad=$ effect of sampling time $(k=1,2 \ldots 10)$

$\mathrm{X}_{\mathrm{lijl}}=\mathbf{3}$ week litter weight

$\mathrm{X}_{2 \mathrm{ijl}}=$ number of live born piglets per litter

$\mathrm{e}_{\mathrm{i}(j) \mathrm{kl}}=$ residual random term
The number of live born piglets per litter was at first included in Model I, but no significant effect was found and the parameter was not included in the model. There was no effect of parity on the colostrum crude protein content (Table 3), nor on the contents of immunoglobulins and accordingly parity was omitted when the effect of feeding on the contents of immunoglobulins was studied. The interaction between $f_{i}$ and $p_{j}$ was tested, but was not found statistically significant.

\section{Results}

The colostrum was obtained on average $5 \mathrm{~h}$ (0 to 15) after farrowing. The $R$ sows had a

Table 3. The composition of colostrum.

\begin{tabular}{|c|c|c|c|c|c|c|c|}
\hline & \multicolumn{2}{|c|}{$\mathrm{C}$} & \multicolumn{2}{|c|}{$\mathbf{R}$} & \multicolumn{3}{|c|}{ Level of sign.++ } \\
\hline & $1 \mathrm{sm}$ & SE & $1 \mathrm{sm}$ & SE & f & $\mathrm{p}$ & $\mathrm{h}$ \\
\hline Dry matter, $\%^{-}$ & 22.4 & 0.28 & 22.9 & 0.28 & NS & NS & **** \\
\hline Crude protein, $\%^{-}$ & 12.4 & 0.27 & 11.9 & 0.28 & NS & NS & $* * *$ \\
\hline Fat, $\%^{-}$ & 6.0 & 0.16 & 7.3 & 0.16 & $* * *$ & $* * *$ & NS \\
\hline Residual solids, $\%^{-}$ & 4.1 & 0.18 & 3.7 & 0.18 & NS & NS & NS \\
\hline $\mathrm{IgA}, \mathrm{mg} / \mathrm{ml}^{+}$ & 24.4 & 2.48 & 14.1 & 2.24 & $*$ & & *** \\
\hline $\mathrm{IgG}, \mathrm{mg} / \mathrm{ml}^{+}$ & 39.3 & 2.00 & 36.2 & 1.90 & NS & & $* * *$ \\
\hline
\end{tabular}

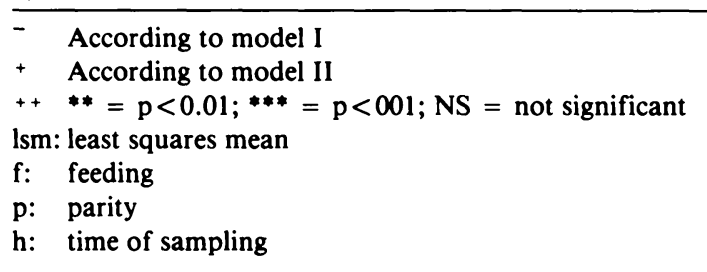


higher colostrum dry matter content than the $C$ sows (Table 3 ). This was due to a significantly higher fat content in the $\mathrm{R}$ sows colostrum. On the other hand, the $C$ sows colostrum contained more crude protein and residual solids than the $R$ sows did. The levels of $\mathrm{IgA}$ and $\mathrm{IgG}$ were higher in the $\mathrm{C}$ sows colostrum compared with the $\mathrm{R}$ sows. The contents of crude protein and immunoglobulins significantly decreased after farrowing. Within the first $4 \mathrm{~h}$ the crude protein content of colostrum decreased by 6 percentage units (Fig. 1).

There was no difference in milk composition at 2 weeks after farrowing between the $\mathrm{C}$ and $R$ sows (Table 4 ). The contents of immunoglobulins and crude protein were much lo-

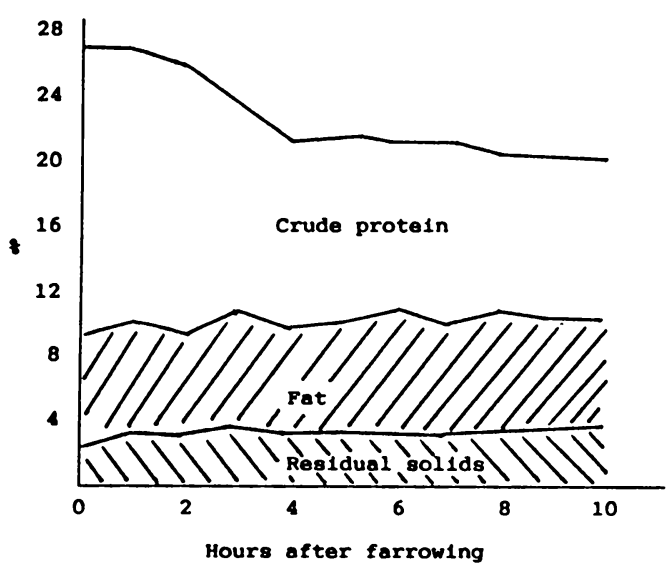

Fig. 1. Change in composition of colostrum after farrowing. wer in the milk compared with the colostrum. However, the residual solid content of the milk was almost 2 percentage units higher compared with colostrum. The fat content of milk and colostrum was about the same.

The milk dry matter content decreased with increasing parity. This was due solely to a difference in the fat content of the milk. Sixth parity sows had 1.4 percentage units lower milk fat content compared to the first parity sows.

Milk composition was significantly affected by the litter weight at 3 weeks after farrowing (Table 5).

Table 5. Regression coefficients $\left(b_{1}\right)$ for litter weight $(\mathrm{kg})$ at 3 weeks on the composition of milk.

\begin{tabular}{lll}
\hline & $\mathrm{b}_{1}{ }^{-}$ & Level of sign. ${ }^{+}$ \\
\hline Dry matter, \% & -0.05 & $* * *$ \\
Crude protein, $\%$ & -0.02 & $* * *$ \\
Fat, \% & -0.03 & $* *$ \\
Residual solids, $\%$ & -0.00 & NS \\
\hline
\end{tabular}

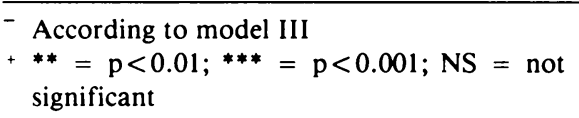

The concentration of $\mathrm{IgG}$ in colostrum was not related to the piglet mortality during the first week of life (Table 6). The frequency of post weaning diarrhoea was on average 10.4 days per litter and could neither be correlated with the amount of crude protein nor to the immunoglobulin content of the milk (Table 6).

Table 4. The composition of milk

\begin{tabular}{|c|c|c|c|c|c|c|}
\hline & \multicolumn{2}{|c|}{$\mathrm{C}$} & \multicolumn{2}{|c|}{$\mathbf{R}$} & \multicolumn{2}{|c|}{ Level of sign. ${ }^{+}$} \\
\hline & $1 \mathrm{sm}^{-}$ & SE & $1 \mathrm{sm}^{-}$ & SE & $\mathrm{f}$ & $\mathrm{p}$ \\
\hline Dry matter, \% & 17.6 & 0.13 & 17.3 & 0.14 & * & * \\
\hline Crude protein, \% & 4.92 & 0.07 & 4.78 & 0.07 & NS & NS \\
\hline Fat, $\%$ & 6.7 & 0.10 & 6.6 & 0.10 & NS & $* * *$ \\
\hline Residual solids, $\%$ & 5.8 & 0.09 & 5.7 & 0.09 & NS & NS \\
\hline $\mathrm{IgA}, \mathrm{mg} / \mathrm{ml}$ & 6.2 & 0.57 & 5.5 & 0.62 & NS & **** \\
\hline $\mathrm{IgG}, \mathrm{mg} / \mathrm{ml}$ & 0.37 & 0.01 & 0.37 & 0.01 & NS & NS \\
\hline
\end{tabular}

- According to model III

$+^{*}=\mathrm{p}<0.05 ;^{* *}=\mathrm{p}<0.01 ;{ }^{* *}=<0.001 ; \mathrm{NS}=$ not significant 
Table 6. Partial correlation coefficients and statistical significance levels between sow colostrum and milk composition and the occurrence of prenatal mortality and post weaning diarrhoea.

\begin{tabular}{lcc}
\hline & $\begin{array}{c}\text { Mortality the } \\
\text { first week of life }\end{array}$ & $\begin{array}{c}\text { Days with post } \\
\text { weaning diarrhoea }\end{array}$ \\
\hline $\begin{array}{l}\text { Colostrum } \\
\text { dry matter }\end{array}$ & $-0.07 \mathrm{NS}^{++}$ \\
crude protein & $0.01 \mathrm{NS}$ & \\
IgG & $0.04 \mathrm{NS}$ & \\
IgA & $0.01 \mathrm{NS}$ & \\
Milk & & $-0.01 \mathrm{NS}$ \\
dry matter & $0.05 \mathrm{NS}$ \\
crude protein & $-0.09 \mathrm{NS}$ \\
IgG & $-0.04 \mathrm{NS}$ \\
IgA & \\
\hline- & \\
\hline & According to model IV & \\
+ According to model III & \\
++ & NS $=$ not significant
\end{tabular}

\section{Discussion}

Sows fed very restrictedly during the last 2 weeks prior to farrowing had higher colostrum fat levels compared with the control sows. This observation was not confirmed by the experiment by Nielsen \& Danielsen (1983) nor by Okai et al. (1977). In these experiments, however, none of the sows were fed as restrictedly as in this trial. One explanation for the increased amount of fat in colostrum of the very restrictedly fed sows in the present investigation can be that sows given an inadequate feed allowance synthesize milk directly from body tissues (de Lange et al. 1980). Moreover the $\mathrm{R}$ sows consumed an appreciable amount of straw, and thereby increased the energy to protein ratio in the total feed ration which also can have been a contributing factor.

The crude protein of the colostrum during the first hours post partum mainly consists of IgG (Curtis \& Bourne 1971, Klobasa et al. 1987). In the present investigation the colostrum samples were collected on average $5 \mathrm{~h}$ post partum. Taking into account only the samples that were collected the first few hours after farrowing, it was found that the levels of dry matter and crude protein were in good agreement with the values reported by Klobasa et al. (1987). However, the concentration of $\mathrm{IgG}$ in the present investigation was not as high as reported by these authors. de Passille' et al. (1988) and Yugachi et al. (1980) reported lower IgG levels in the serum of piglets that had died compared with the survivors. In this investigation no relationship was found between the concentration of IgG in colostrum and mortality in the first week.

The variation in the immunoglobulin content of colostrum between sows is very high (Klobasa \& Butler 1987). In the present investigation the effects of grand sire and number of live born piglets per litter was at first included in the statistical analyses, but were not found to significantly affect the composition of the colostrum or the milk, and were consequently omitted from the analyses. This is in agreement with de Passille' et al. (1988), who found no relationship between the number of live born piglets per litter and the immunoglobulin content of colostrum. The IgG content of the milk 2 weeks after farrowing was very low and the concentra- 
tion of $\operatorname{IgA}$, which is the main factor in the immunological system at this stage of lactation, was much higher.

Allen \& Lasley (1960) stated that litter weight at weaning was significantly correlated with milk yield. The negative relationships between the 3 week litter weight and the contents of milk dry matter, crude protein and fat in the present investigation indicate that milk yield is negatively correlated with the milk dry matter, crude protein and fat contents.

\section{References}

Agricultural Research Council: The nutrient requirements of farm livestock. No 3. Pigs. Agricultural Research Council, London, 1967.

Allen AD, Lasley JF: Milk production of sows. J. Anim. Sci. 1960, 19, 150-155.

Curtis J, Bourne FJ: Immunoglobulin quantitation in sow serum, colostrum and milk and the serum of young pigs. Biochim. Biophys. Acta. 1971, 236, 319-332.

de Lange PGB, van Kempen GJM, Klaver J, Verstegen MWA: Effect of condition of sows on energy balances during 7 days before and 7 days after parturition. J. Anim. Sci. 1980, 50, 886.

de Passille' AMB, Rushen J, Pelletier G: Sucking behaviour and serum immunoglobulin levels in neonatal piglets. Anim. Prod. 1988, 47, 447-456.

Elsley FWH: Nutrition and lactation in the sow. In Falconer, Ed. Lactation. Butterworths, London, 1970.

Goransson L: The effect of feed allowance in late pregnancy on the production traits of sows and litters. 1988. Submitted.

Göransson L: The effect of feed allowance in late pregnancy on the occurrence of agalactia post partum in the sow. J. Vet. Med. A. 1989, 36, 505513.

Hovell DeBFD, MacPherson RM: Thin sows. 1. Observations on the fecundity of sows when underfed for several parities. J. Agric. Sci. Camb. 1977, 89, 513-522.
Klaver J, van Kempen GJM, de Lange PGB, Verstegen $M W A$, Boer $H$ : Milk composition and daily yield of different milk components as affected by sow condition and lactation/feeding regimen. $J$. Anim. Sci. 1981, 52, 1091-1097.

Klobasa F, Butler JE: Absolute and relative concentration of immunoglobulins $G, M$ and $A$, and albumin in the lacteal secretion of sows of different lactation numbers. Amer. J. vet. Res. 1987, 48, 176-182.

Klobasa F, Werhahn E, Butler JE: Composition of sow milk during lactation. J. Anim. Sci. 1987, 64, 1458-1466.

Lizane J, Hellsing K: Manual immunonephelometric assay of proteins with use of polymer enhancement. Clinical Chemestry 1974, 20, 1181.

Nielsen H, Danielsen V: To energinormer og to proteinnormer till draegtige søer. (Different energy and protein allowances for pregnant sows). Statens Husdyrbrugsforsøg. Meddelelse nr. 461. København, 1983.

O'Grady JF, Elsley FWH, MacPherson RM, McDonald I: The response of lactating sows and their litters to different dietary energy allowance. I. Milk yield and composition, reproductive performance of sows and growth rate of litters. Anim. Prod. 1973, 17, 65-74.

Okai DB, Aherne FX, Hardin RT: Effects of sow nutition in late gestation on the body composition and survival of the neonatal pig. Can. J. Anim. Sci. 1977, 57, 439-448.

Persson A, Pedersen A, Göransson L, Kuhl W: A long term study on the health status and performance of sows on different feed allowances during late pregnancy. Acta Vet. Scand. 1989, 30, 9-17.

SAS Institute Inc.: SAS User's Guide. SAS Institute Inc., Cary. 1985. North Carolina.

Yugachi H, Murata H, Kagota K, Namioka S: Studies on the relationship between the serum gamma globulin levels of neonatal piglets and their mortality during the first two months of life: on evaluation for the ammonium sulphate reaction. Brit. vet. J. 1980, 136, 63-70. 


\section{Sammanfattning}

Inverkan av utfodning under sen dräktighet pả sammansättningen av kolostrum och mjolk hos sugga

Kolostrum och mjollk från suggor utfodrade med 3.4 eller $1.0 \mathrm{~kg}$ per dag de sista 14 drăktighetsdagarna analyserades. De mycket restriktivt utfodrade djuren hade lăgre fetthalt $\mathrm{i}$ kolostrum jămfort med kontrollsuggorna. De forsta 4 timmarna efter grisning sjönk kolostrums innehåll av ráprotein och immu- noglobuliner mycket. Mjolkens sammansăttning 14 dagar efter grisning páverkades inte av fodergivan under högdrăktighet. Grisarnas 3-veckorsvikt var signifikant korrelerad med mjolkens sammansăttning. Innehállet av IgG i kolostrum var inte korrelerad med smågrisdődigheten den fơrsta levnadsveckan. Mjölkens innehåll av råprotein och immunoglobuliner påverkade inte frekvensen avvănjningsdiarré.

(Received April 24, 1989; accepted June 1, 1989).

Reprints may be requested from: Leif Gorransson, Swedish Pig Center, S-26800 Svalöv, Sweden. 